\title{
Uncommon Cause of Knee Pain in Behçet's Disease: Suprapatellar Synovial Chondromatosis
}

\author{
Behçet Hastasında Nadir Diz Ağrısı Nedeni: Suprapatellar Sinoviyal Kondromatozis
}

Fatih Bağcıer, Ahmet Çelik, Akın Erdal

Atatürk University Faculty of Medicine, Department of Physical Medicine and Rehabilitation, Erzurum, Turkey

\section{To the Editor;}

A 44-year-old male patient with Behçet's disease presented to our clinic with progressively worsening right knee pain and suprapatellar swelling. The knee pain started about a month previously and increased over time. The characteristic of the pain was mechanical. He did not feel pain while sleeping. Previously, he had received analgesic medications but there had been no significant improvement. There was no pain in any other joint, and there was no history of disease or trauma and arthritis attack associated with the knee. The patient had a history of Behçet's disease for five years and patient was using colchicine $3 \times 1$ pozology a day. On physical examination there was no arthritis findings. Patella shock test was negative. The patient was seen to have visibly swollen suprapatellar area. On palpation the swelling was hard, non-mobile, well defined, and measured 2x1 $\mathrm{cm}$. Radiography of the knee indicated multiple soft tissue calcifications outside the joint capsule of the right knee. Knee magnetic resonance imaging revealed expanded sinovium that contained osteochondromas, which were hypointense all sequences (Figure 1). The patient's blood tests were normal. Arthroscopic debridement were performed with symptomatic right knee joint. Pathology results were evaluated as synovial chondromatosis (SC).

SC is a rare arthropathy of unknown etiology. The disease is generally monoarticular, usually occurs unilaterally in the large joints like the knee, hip, and elbow (1). Primary or idiopathic form may occur in an otherwise normal joint, but secondary SOC may occur due to trauma or degenerative diseases. On the other hand, it may occur in the setting of preexistent osteoarthritis, rheumatoid arthritis, osteonecrosis, osteochondritis dissecans, neuropathic osteoarthropathy, tuberculosis, or osteochondral fractures $(2,3)$. To the best of our knowledge, the suprapatellar SOC of the knee in a Behçet disease is rare, and this encouraged us to report this case. Secondary SC should be included in the differential diagnosis of Behçet disease's joint pain.

Keywords: Behçet's disease, knee pain, suprapatellar synovial chondromatosis

Anahtar kelimeler: Behçet hastalığı, diz ağısı, suprapatellar sinoviyal kondromatozis

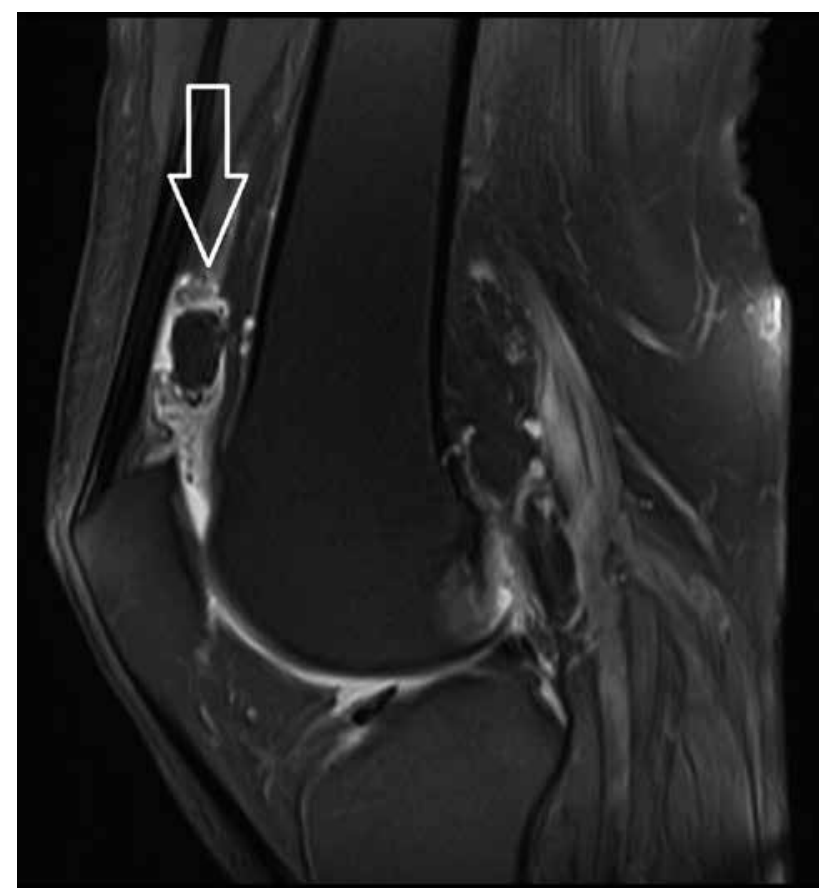

Figure 1. Magnetic resonance imaging revealed findings consistent with synovial osteochondromatosis in the right suprapatellar area

Address for Correspondence/ Yazışma Adresi: Fatih Bağcıer MD, Haydarpaşa Numune Training and Research Hospital, Clinic of Physical Medicine and Rehabilitation, İstanbul, Turkey Phone: +90 5056605754 E-mail: bagcier_42@hotmail.com Received/Geliş Tarihi: 11.12.2015 Accepted/Kabul Tarihi: 28.12.2015 


\section{Ethics}

Informed Consent: A consent form was completed by all participants.

Peer-review: Internally peer-reviewed.

\section{Authorship Contributions}

Surgical and Medical Practices: Fatih Bağcıer, Ahmet Çelik, Akın Erdal, Concept: Fatih Bağcıer, Design: Fatih Bağcler, Surgical and Medical Practices: Fatih Bağcıer, Analysis or Interpretation: Fatih Bağcıer, Literature Search: Fatih Bağcıer, Writing: Fatih Bağcıer. Conflict of Interest: No conflict of interest was declared by the authors.
Financial Disclosure: The authors declared that this study received no financial support.

\section{References}

1. Llauger J, Palmer J, Roson N, Bague S, Camins A, Cremades R. Nonseptic monoarthritis: imaging features with clinical and histopathologic correlation. Radiographics 2000;20 Spec No: 263-78.

2. Shearer $H$, Stern $P$, Brubacher $A$, Pringle $T$. A case report of bilateral synovial chondromatosis of the ankle. Chiropr Osteopat 2007;15:18

3. Moll C, Bogas M, JA G-P, Celis R, Vázquez I, Rodríguez F, et al. Macroscopic features of knee synovitis in early untreated Behçet disease and psoriatic arthritis. Clinical Rheumatology 2009;28:1053-7. 